\title{
Bioactivity of Some Plant Extracts Against Termite Odontotermes obesus (Rambur) (Blattodea: Termitidae)
}

Khalid Zamir Rasib ${ }^{1^{*}}$, Arooj Arif ${ }^{1}$, Ayesha Aihetasham ${ }^{2}$ and Dildar Ahmad Alvi ${ }^{1}$

${ }^{1}$ Department of Biological Science, Forman Christian College University, Lahore 54600, Pakistan

${ }^{2}$ Department of Zoology. Punjab University, New Campus Lahore-54660, Pakistan

*Corresponding author: Khalid Zamir Rasib, Department of Biological Science, Forman Christian College University, Lahore 54600, Pakistan, Tel: (92 42) 99231581-8, E-mail: Khalidrasib786@gmail.com

Received Date: September 29, 2017; Accepted Date: December 19, 2017; Published Date: December 30, 2017

Copyright: (c) 2017 Rasib KZ, et al. This is an open-access article distributed under the terms of the Creative Commons Attribution License, which permits unrestricted use, distribution, and reproduction in any medium, provided the original author and source are credited.

\begin{abstract}
A study was carried out to determine the chemical constituents of wood extractives from Ashoka, Saraca asoca (Roxb) and Magnolia (Magnolia grandiflora L.) (Southern Magnolia) against Odontotermes Obesus (Rambur) under laboratory conditions in Forman Christian College University (Lahore, Pakistan) in June 2016. Extraction was done by soxhlet apparatus. The analysis of these compounds was performed by Gas Chromatography-Mass Spectrometry (GC-MS). Gas Chromatography-Mass Spectrometry of wood extractives of Saraca asoca detected 4-[(1E)-3-Hydroxy-1-propenyl]-2-methoxyphenol; Hexdecanoic acid, methyl ester; n-Hexadecanoic acid; 5,6-Dimethoxy phthalaldehydic acid; 9,12-Octadecadienoic acid, methyl ester, (E,E)-; 9,12-Octadecadienoic acid (Z,Z)-; Oleic acid; Octadecanoic acid; 1,2-Benzenedicarboxylic acid, mono(2-ethylhexyl) ester. Compounds in wood extractives of Magnolia grandiflora were Cyclopentane carboxylic acid, 2-methyl-4-(phenylmethylene)-, methyl ester; 4-((1E)-3-Hydroxy-1-propenyl)-2methoxyphenol; $n$-Hexadecanoic acid; 5,6-Dimethoxy phthalaldehydic acid; 7-(1,3-Dimethylbuta-1,3dienyl)-1,6,6-trimethyl-3, 8-dioxatricyclo[5.1.0.0(2,4)]; 9,12-Octadecadienoic acid, methyl ester, (E,E)-; Oleic acid; 16-Methyloxacyclohexadeca-3,5-dien-2-one; Germacra-1(10), 4,11(13)-trein-12-oic acid, 6.alpha.-

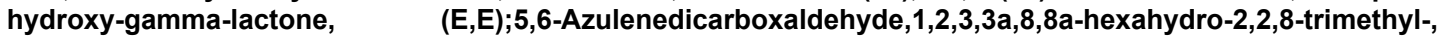
(3a.alpha.,8.alpha.,8a.alpha)-(-)-; Aromadendrene oxide-(2); Cedran-diol, 8S, 14-; Cis-Z-.alpha.-Bisabolene epoxide; 2-Dodecen-1-yl(-)succinic anhydride; 3-Buen-2-ol, 2-methyl-4(1,3,3-trimethyl-7oxabicyclo[4.1.0]hept-2-yl)-.Based on the feeding activity, wood extracts were arranged in descending order of preference; Ashoka > Magnolia. So these could prove useful in developing a soil barrier to block termite activity and serve as a replacement to synthetic chemicals.
\end{abstract}

Keywords: Biological control; Termites; Species; Evaluation; Saraca asoca; Anti-microbial

\section{Introduction}

Biological control is generally visible as both providing a permanent solution to the pest problem and less degradation of the environment [1]. Termites are the main source of wood degradation in the tropics and subtropical regions [2,3]. Termites are predominant members of the insect order, Isoptera now blattodea and more than 2600 species of termites are found around the world [4,5]. Ecologically, termites are classified under three main groups based on their feeding and nesting behavior: damp wood termites, dry wood termites and subterranean termites [6]. Termites are of great economic importance as they damage a great variety of wood in buildings, crops, local plantation and forests. For the prevention of heavy timber damage, we need allembracing knowledge of natural resistance of native plants to termites and their feeding preference [7]. There are 51 species of termites present in Pakistan thriving diverse ecological zones with 11 pest species, which are playing havoc [8]. In the past, the control of termites was totally based on the synthetic insecticides especially the persistent organochlorine [9-11]. Residual effects, and development of resistance in target pests, are considered as major drawbacks. Also, adverse effects on human health and concerns about environmental deterioration $[12,13]$ have given impetus to the replacement of synthetic insecticides with biorational approaches and is now universally accepted and practiced worldwide. Magnolia grandiflora $L$. belongs to family Magnoliaceae. It is commonly known as Southern magnolia. Its wood color is light, with white sapwood and light to dark brown heartwood. It is highly resistant to shock, will not shrink, and holds nails well [14]. It is used for furniture, cabinets, paneling, veneer, boxes, and crates $[14,15]$. Seeds are eaten by squirrel, opossum, quail, turkey, mice, and chipmunks [15]. Seeds are high in fat and are a good energy source for migratory birds [16]. They are eaten by eastern kingbirds, mockingbirds, robins, wood thrushes, and red-eyed vireos. Pollinators, especially beetles, are attracted to the pollen that is high in protein. A variety of extracts have been taken from leaves, fruits, bark, and wood for pharmaceutical applications [15]. It is a plant of medicinal significance and also grown as an ornamental tree. Its flowers are used in various traditional herbal remedies. Different phytochemicals like alkaloids, carbohydrates, flavonoids, glycosides, gums \& mucilage, phenolic, phlobatannins, reducing sugar, saponins, steroids, tannins and terpenoids in variable amount. The diversity of phytochemicals in this species is justifying the cause of its utility in modern medical investigations and even in traditional plant based remedies. An aqueous extract of seed cones of this plant had induced apoptosis against B-cell lymphocytic leukemia (B-CLL). This shows the curative potentiality of this species. Additionally, the flower extract has antioxidant activity and is also known to decrease the melanin content. The leaves have shown antimicrobial property and phytotoxic effect on 
bean, corn and tobacco grown under greenhouse conditions. In recent years, various plant parts of this species were found to have anticancerous, anti-depressant, antioxidant, and anti-inflammatory etc. properties. The genus is known to have nearly 255 different constituents including alkaloids, flavonoids, and terpenoids. Keeping in view the medicinal importance of this species, present investigation has been carried out to characterize the species on morphological basis and to screen seeds and leaves for various photochemical. Saraca asoca which is also called Saraca indica is the ancient tree of the family Caesalpinaceae. This tree is considered as the first in medicinal values since the Buddhist period and also, the lord Buddha is believed to be born under the asoca tree. It is commonly called as "Ashoka "which is a Sanskrit word meaning "without sorrow". It is believed that the very touch of asoca tree removes the worries and anxiety of human being in Hindu culture. It is believed from ancient period of time that asoca tree is close to women's physical and mental health and also it is a tree of peace and happiness. It is traditionally found in India, Burma and Malaya. In India; it belongs to the Deccan plateau, Western Ghats, Himalaya, and Bengal. Ashoka is $10-15 \mathrm{~m}$ tall with long, beautiful, green foliage and attractive, a fragrant bunch of flowers with yellow and orange colors. In India, Ashoka is traditionally used in the treatment of excessive uterine bleeding, dysmenorrhea and depression in women. It is also used to treat inflammation, indigestion and also abnormal vaginal discharge. It is found to have anti-microbial, anticancer, anti-haemorrhagic, anti-oxytocic activities.

\section{Materials and Methods}

\section{Selection of plant species}

Commercial timbers were selected for experiments. All the wood species were cut from standing trees. Following plant species were used for subsequent studies of their effects on the termites. All the plant species were collected from the botanical garden of Forman Christian College Lahore, Pakistan.

\section{Extraction method for crude extracts of the wood}

Crude extracts of the wood, a non-polar and polar solvents, methanol, was used by incubating sawdust of Magnolia (Magnolia grandiflora) and Ashoka (Saraca asoca) in order to remove moisture. The samples were then preserved in zip lock bags for future use and to avoid any contamination. One hundred gm of saw dust of each wooden species with solvent were placed separately in a Soxhlet extractor and extracted with $150 \mathrm{ml}$ of methanol according to ASTM (2003) standards. After extraction, each extract was kept separately under refrigeration at $4^{\circ} \mathrm{C}$ and subsequently the bioactivity of the extracted compounds was checked against termites.

\section{Gas chromatography-mass spectrometry}

For the identification of components, extracts from the Soxhlet extractor were processed through hydro distillation, for GC-MS analysis. Samples were distilled below $200^{\circ} \mathrm{C}$ and filtered through 0.20 $\mu \mathrm{m}$ pore size filter paper. The gas chromatography temperature ranged of 60 to $310^{\circ} \mathrm{C}$ with $10^{\circ} \mathrm{C} / \mathrm{min}$, with a solvent delay of $4 \mathrm{~min}$. The temperature of the injector was $240^{\circ} \mathrm{C}$. The inert gas was helium at a flow rate of $1.0 \mathrm{~mL} / \mathrm{min}$, and $2 \mu \mathrm{L}$ of sample was injected sample in the split less mode. The percent composition of the samples was calculated. The quantitative analysis was based on the percent area of each peak of the sample compounds. The mass spectrum of each compound was compared with those of NIST 98 (Mass Spectral Library, National Institute of Standards and Technology, MD, USA).

\section{Collection of Odontotermes Obesus}

Odontotermes obesus were collected mainly from Forman Christian College botanical garden. Some were also collected through the baiting already buried wooden blocks in the field about 4-5 months in the buckets. Collection were made feasible using artificial baiting methods such as bucket traps, wetted toilet rolls, and cardboard in of plastic bottles with small holes in the base and sides to permit the entry of termites. The baits were buried in soil and termites were collected as and when required. Termites after collection were first acclimatized under lab conditions for $2-3$ days/72hrs and then used for experimentation.

\section{Evaluation of feeding preferences}

Feeding bioassays choice and repellency bioassay: Repellent responses of wood extracts from Magnolia grandiflora (Magnolia) and Saraca asoca (Ashoka), were observed against $O$. obesus by cutting Whatman filter paper No. 1 into two halves according to size of Petri dish $(70 \times 10 \mathrm{~mm})$ and placed into the dish in such a way that there was space between two halves to allow separate treatment. One half was treated with specific amount of plant extracts $3 \%, 6 \%, 9 \%, 12 \%$ and distilled water was treated as control. Then filter papers were air dried for few minutes. Three replicates of each extract including control were prepared. Ten mature workers and 1 soldier (ratio $10 \mathrm{~m}: 1$ s) of O. obesus were released separately into each dish between treated and untreated zone and observations were made at 15 min intervals. After introduction of termites into the dishes, the number of termites oriented towards the control half were counted as repelled. A treatment concentration was considered repellent when 21 (sum of three replicates) of 30 termites were present on untreated area against respective percent concentration.

No choice test under laboratory conditions: Filter paper for each concentration Magnolia (Magnolia grandiflora) and Ashoka (Saraca asoca) was treated separately as mentioned above to evaluate the mortality and feeding of O.obesus. Termite mortality was recorded periodically during the bioassays up to 7 days. Percentage mortality was calculated using the following formula-

$$
\mathrm{M}_{c}=\left(\mathrm{M}_{o}-M_{e}\right) /\left(100-M_{e}\right) \times 100
$$

Where, $\mathrm{Mo}=$ mortality rate of treated termite $(\%), \mathrm{Me}=$ mortality rate of control (\%), $\mathrm{Mc}=$ corrected mortality rate (\%).

Statistical analysis: Data were analyzed statistically by using co-stat and standard deviation to evaluate the consumption, mortality on the wooden extracts against $O$. obesus in Anova Test. Results were statistically significant in all cases $(\mathrm{P}<0.05)$.

\section{Results}

Compounds identified in extracts of Magnolia (Magnolia grandiflora L.) and Ashoka (Saraca asoca) (Roxb).

Compounds identified in gas chromatography using methanol as extraction solvent are given in Table 1. 
Citation: Rasib KZ, Arif, Aihetasham, A, Alvi DA (2017) Bioactivity of Some Plant Extracts Against Termite Odontotermes obesus (Rambur) (Blattodea: Termitidae). J Biodivers Biopros Dev 4: 167. doi:10.4172/2376-0214.1000167

Page 3 of 7

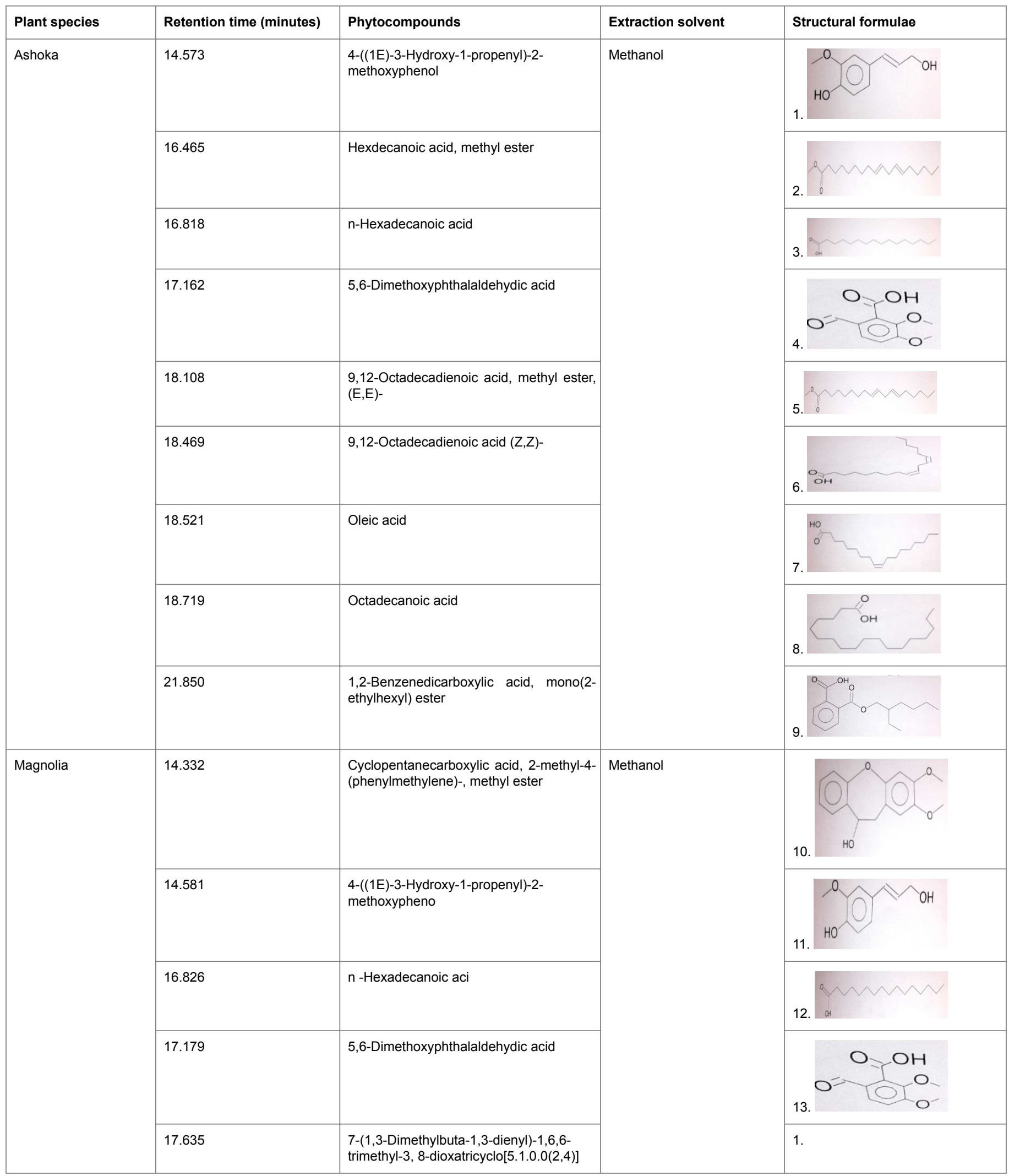


Citation: Rasib KZ, Arif, Aihetasham, A, Alvi DA (2017) Bioactivity of Some Plant Extracts Against Termite Odontotermes obesus (Rambur) (Blattodea: Termitidae). J Biodivers Biopros Dev 4: 167. doi:10.4172/2376-0214.1000167

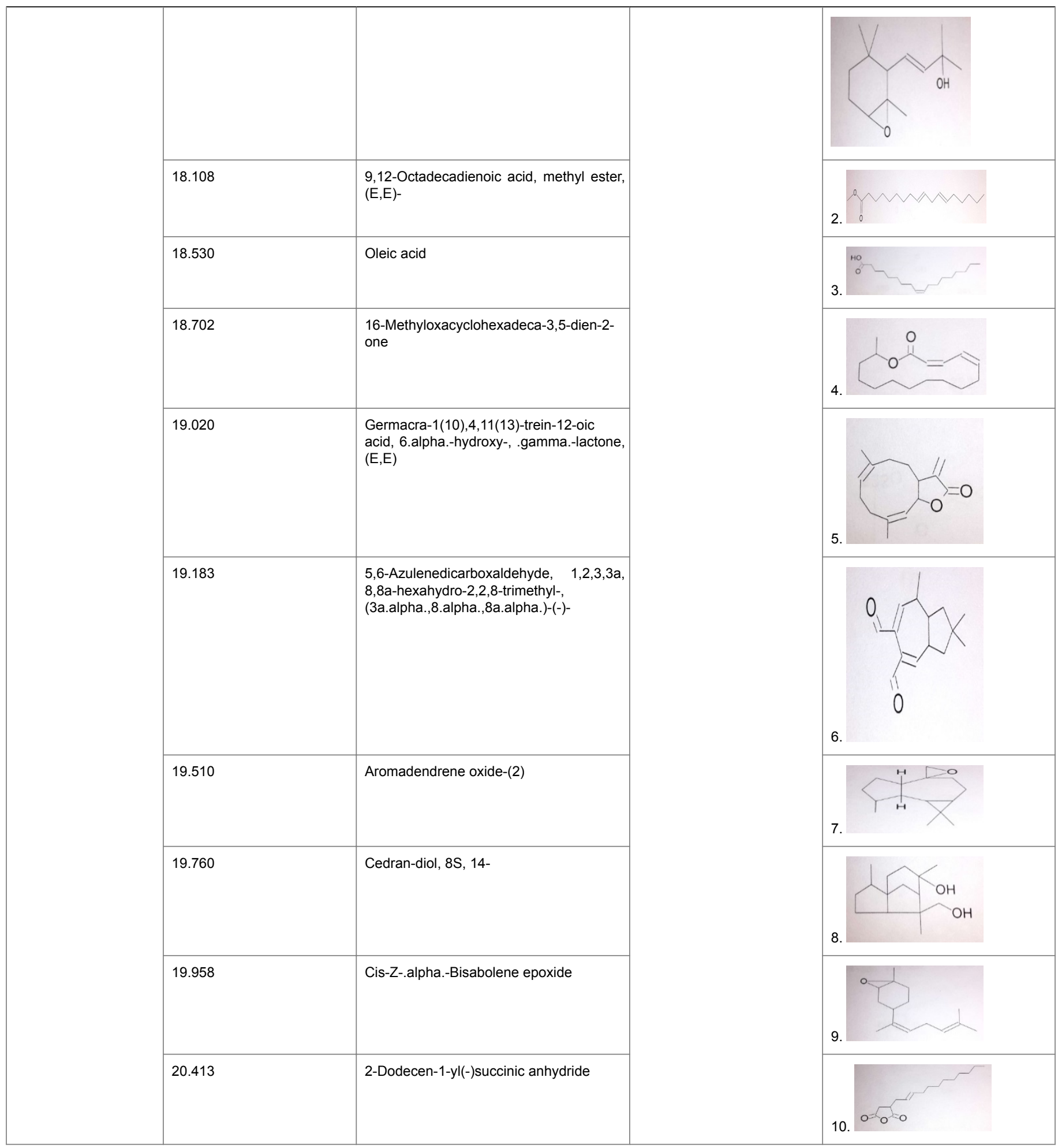




\begin{tabular}{|l|l|l|l|l|}
\hline 21.463 & $\begin{array}{l}\text { 3-Buen-2-ol, 2-methyl-4(1,3,3-trimethyl-7- } \\
\text { oxabicyclo[4.1.0]hept-2-yl)- }\end{array}$ & & 11. \\
\hline
\end{tabular}

Table 1: Phytocompounds identified in chromatogram of Magnolia (Magnolia grandiflora) and Ashoka (Saraca asoca) using methanol as extraction solvent.

\section{Effect of wood extracts on Odontotermes obesus under laboratory conditions}

No choice laboratory trials: Table 2 indicates mean average mortality as a result of direct treatment of crude extract treatment on filter paper after 7 days; Maximum 20.0\% mortality was seen in extracts of Saraca asoca against termite Odontotermes obesus. Minimum mortality of $10.0 \%$ was recorded in extract of Magnolia grandiflora. Statistical analysis in combination indicates significant $(\mathrm{P}>0.05, \mathrm{~F}=6.41)$ results.

\begin{tabular}{|l|l|l|l|}
\hline $\begin{array}{l}\text { Plant extract } \\
\text { Used }\end{array}$ & Scientific Name & $\begin{array}{l}\text { Mean average } \\
\text { Mortality }\end{array}$ & $\begin{array}{l}\text { Anova Test } \\
\text { *Probability }\end{array}$ \\
\hline Magnolia & $\begin{array}{l}\text { Magnolia } \\
\text { grand flora L }\end{array}$ & $10.0 \%$ & $\begin{array}{l}\mathrm{P}>0.05 \\
{ }^{*} \mathrm{P}=0.035 \\
\mathrm{~F}=6.41\end{array}$ \\
\hline Ashoka & $\begin{array}{l}\text { Saraca asoca } \\
\text { (Roxb) }\end{array}$ & $20.0 \%$ & \\
\hline
\end{tabular}

Table 2: Average mortality and standard error of Odontotermes obesus, after 07 Days as a result of direct treatment of crude extracts with the filter paper.

Table 3 shows workers of Odontotermes obesus exposed to different concentrations of $3 \%, 6 \%, 9 \%$ and $12 \%$ of extracts of Magnolia (Magnolia grandiflora) respectively. The highest feeding \% age was observed at $3 \%$ of concentration with $85.5 \%$ feeding. The lowest feeding $\%$ age was observed at $12 \%$ of concentration with $67.5 \%$ feeding.

\begin{tabular}{|c|c|c|c|c|}
\hline $\begin{array}{l}\text { Wood Extract } \\
\text { used }\end{array}$ & $\begin{array}{l}\text { Scientific } \\
\text { Name }\end{array}$ & $\begin{array}{l}\text { Conc. } \\
\text { Used (\%) }\end{array}$ & $\begin{array}{l}\text { Mean } \\
\text { Termite } \\
\text { feeding }(g) \pm \\
\text { SE }\end{array}$ & $\begin{array}{l}\text { Feeding } \\
\text { \%age }\end{array}$ \\
\hline \multirow[t]{4}{*}{ Magnolia } & \multirow{4}{*}{$\begin{array}{l}\text { Magnolia } \\
\text { grandiflora L. }\end{array}$} & 3 & $0.34 \pm 0.004$ & 85.0 \\
\hline & & 6 & $0.33 \pm 0.004$ & 82.5 \\
\hline & & 9 & $0.31 \pm 0.004$ & 77.5 \\
\hline & & 12 & $0.27 \pm 0.005$ & 67.5 \\
\hline \multirow[t]{4}{*}{ Ashoka } & \multirow{4}{*}{$\begin{array}{l}\text { Saraca asoca } \\
\text { (Roxb) }\end{array}$} & 3 & $0.34 \pm 0.004$ & 85.0 \\
\hline & & 6 & $0.32 \pm 0.004$ & 80.0 \\
\hline & & 9 & $0.30 \pm 0.001$ & 75.0 \\
\hline & & 12 & $0.26 \pm 0.005$ & 65.0 \\
\hline
\end{tabular}

Table 3: Average feeding (g) and SE on filter paper by Odontotermes obesus exposed for 7 days to varying concentrations of wood extracts of Magnolia (Magnolia grandiflora) and Ashoka (Saraca asoca).
Table 3 shows workers of Odontotermes obesus exposed to different concentrations of 3, 6, 9 and 12 of extracts of Ashoka (Saraca asoca) respectively. The highest feeding $\%$ age was observed at $3 \%$ of concentration with $85.0 \%$ feeding. The lowest feeding $\%$ age was observed at $12 \%$ of concentration with $65.0 \%$ feeding.

Choice test and repellency bioassay: When workers of Odontotermes obesus were exposed to Magnolia (Magnolia grandiflora) extracts to detect the repellency on treated and untreated filter paper in Petri dishes. There were repellent effects on termites, which moved from treated to untreated; at 6\%, 20 termites were observed; at 9\%, 22 termites were observed; at 12\%, 17 termites were observed on untreated filter paper. However, at 3\%, concentration 23 termites were present on untreated filter paper indicating repellency. When workers of Odontotermes obesus were exposed to Ashoka (Saraca asoca) extracts to detect the repellent and attractive effects on treated and untreated filter paper in Petri dishes. There were repellent effects on termites, which moved from treated to untreated at $6 \%, 16$ termites were observed; at 9\%, 15 termites were observed; at $12 \%, 12$ termites were observed on untreated filter paper. However, at 3\%, concentration 24 termites were present on untreated filter paper indicating repellency. In magnolia 3 and $9 \%$ concentration were repellent and in Ashoka only $3 \%$ concentration was repellent (Table 4).

\begin{tabular}{|l|l|l|}
\hline \multirow{4}{*}{ Plant Species } & $\begin{array}{l}\text { Concentrations used } \\
(\%)\end{array}$ & $\begin{array}{l}\text { Repellent } \\
\text { Effects on } \\
\text { termites }\end{array}$ \\
\hline \multirow{4}{*}{ Magnolia (Magnolia grandiflora) } & 3 & 23 \\
\cline { 2 - 3 } & 6 & 20 \\
\hline \multirow{3}{*}{ Ashoka (Saraca asoca) } & 9 & 22 \\
\cline { 2 - 3 } & 12 & 17 \\
\hline & 3 & 24 \\
\cline { 2 - 3 } & 6 & 16 \\
\cline { 2 - 3 } & 9 & 12 \\
\cline { 2 - 3 } & 12 & 15 \\
\hline
\end{tabular}

Table 4: Repellency and choice bioassays against termite Odontotermes obesus (Rambur) treated at different concentrations of Magnolia and Ashoka plant species.

\section{Discussion}

In the past, the control of termites has been totally based on chemicals especially synthetic insecticides such as persistent organochlorine (OC) and organophosphate (OP) insecticides [10, 17]. The residual effects as well as the development of insecticide resistance in 
target pests with environmental degradation, health effects, are some of the concerns in applying wider use of pesticides [18]. Replacement of synthetic by bio-rational insecticides is accepted worldwide and is thought to be a bio-rational approach [19]. In this respect bioactive compounds are much safer option and an alternative option to manage termites. The plant extracts are investigated for multidimensional approaches like, insecticidal, repellent, and antifeedant properties [20, 21]. The chemicals defense in plants offer such promise of developing them as insecticides could prove effective against termites and other arthropods in management and replacement of prevalent application of insecticides in the environment [22]. In recent years, the biorational botanical insecticides gaining momentum in terms of the application along with termite control. The Lemon grass (Cymbopogon Citratus), Cassia leaf (Cinnamomum cassia), Vetiver (Vetiveria zizaniodes), Eucalyptus (Eucalyptus citrodora, Eucalyptus globules), Cedar wood (Cedrus atlantica), Clove bud (Syzgium aromaticum) [20], Coleus amboinicus [23], Isoborneol [24] and Calotropis procera [25] are some of plants possessing anti-termite activities. The application of plant extracts along with their biocompounds when applied to termites using diverse solvents adversely effected termite behavior and subsequent their mortality [26-29]. The insecticidal activity of seed oil of $J$. curcas has several sterols and terpene alchohols [30]. The maximum wood protection against $O$. obesus and Microcerotermes beesoni termites by $J$. curcas oil and its toxic fraction were obtained at their highest concentration i.e., 20\% [31]. Termite investigators in other parts of the world emphasised on Leaf and seed extracts of Jatropha curcas Linn. in various polar and non-polar solvents were used against workers and soldiers of subterranean termites, Odontotermes obesus (Ramb.) to determine the consequence on mortality and tunneling behavior. The reduction in tunnel length $(\mathrm{mm})$ was observed in all extracts and was significantly different from their respective controls. Results are discussed in relation to possible differences of activities in various extracts towards mortality and tunneling of the termites. Wild Solanum nigrum contain higher concentrations of solanidine which it has toxicity on the potato tuber moth [32]. Ganapaty et al. [33] who noted that quinones extracted from the roots of Diospyros sylvatica caused higher mortality in the termite, Odontotermes obesus. Methanol extract of Eugenia caryophyllata bud $(5.2 \mathrm{mg} / \mathrm{cm} 2)$ caused $100 \%$ mortality of Attagenus unicolor Japonicus during seven days after treatment [34]. The crude water extracts of Larix keptolepis wood containing flavonoids in large quantities exhibited potent termite, Coptotermes formosanus, feeding deterrent activities [35]. Gut microbes in Formosan subterranean termite Coptotermes formosanus were affected when the neem extract was mixed with the food source [36]. The 5\% chloroform extract of Lantana camara was found to be significantly effective against termite workers [37]. Manzoor et al. [28] report that activity of crude plant extracts against termites is often attributed to complex mixture of active compounds and that Ethyl acetate extract of Ocimum sanctum $L$ The crude extract of the leaves or fruits of $S$. incanum and $W$. somnifera are potentially useful as termite control agents in the termite breeding places in either the field or in infected houses. Mortalities in M. obesi were $100.00 \pm 0.00,91.06 \pm 3.16$ and $85.82 \pm 2.17$ at high, medium and low concentrations of leaf extract of E. helioscopia, respectively in 11th day. Mean mortality in $O$. lokanandi were $100 \pm$ $0.00,93.32 \pm 3.35$ and $78.83 \pm 5.29$ at high, medium and low concentrations of leaves of E. helioscopia, respectively in 7th day. Mean mortalities in $M$. obesi were $100.00 \pm 0.00,100.00 \pm 0.00$ and $95.80 \pm$ 1.03 at high, medium and low concentrations of leaf aqueous extracts of Calotropis procera in day 11 of the trial. the effects of leaf aqueous extracts of Calotropis procera when offered to workers and soldiers of
Odontotermes lokanand for seven days in the form of soaked filter paper, percent mean mortality was $100.00 \pm 0.00,93.71 \pm 1.83$ and $87.43 \pm 2.03$ at high, medium and low concentrations respectively. Essential oils and plant extracts are still an important natural resource of pesticides/ insecticides [38,39] or larvicides [40,41] or insect repellents $[42,43]$. The present studies show that mean \% mortality recorded in $O$. obesus is $20 \%$. Workers of O. obesus exposed to different concentrations of 3,6,9 and $12 \%$ of extracts of Ashoka (Saraca asoca) respectively. The highest feeding \% age was observed at $3 \%$ of concentration with $85.0 \%$ feeding. The lowest feeding $\%$ age was observed at $12 \%$ of concentration with $65.0 \%$ feeding, which means if the percentage of concentration is increased significantly then it could control termite and activity of plant extracts against termites is often attributed to complex mixture of active phytocompounds. Screening for anti-termitic activity of plant extracts with medicinal attributes could lead to the discovery of new agents for termite control.

\section{References}

1. Howarth FG (1991) Environment impact of classical biological control Annu. Rev. Entomol 36: 485-509.

2. Peralta RCG, Menezes EB, Carvalho AG, Menezes ELA (2003) Feeding Preferences of Subterranean Termites for Forest Species associated or not to Wood Decaying Fungi. Floresta e Ambiente 10: 58-63.

3. Peralta RCG, Menezes B, Carvalho, AG, Aguiar M (2004) Wood consumption rates of forest species by subterranean termites under field conditions. Sociedade de Investigações Florestais, 28: 83-289.

4. Kambhampati S, Eggleton P (2000) Taxonomy and Phylogenetics of Isoptera. In: Abe T, Bignell DA, Higashi M, Eds. Termites: Evolution, Sociality, Symbioses and Ecology, Kluwer Academic Publishers, Dordrecht, 1-23.

5. Eggleton P (2000) Evolution, Sociality, Symbiosis, Ecology (eds T.Abe, D. E.Bignell \& M.Higashi): Global patterns of termite diversity. Termites, Kluwer Academic Publications. Dordrecht, The Netherlands, pp. 25-52.

6. Chung KM, Lee (1999) Urban Pest Control - A Malaysian Perspective: Termites. In: Lee CY, Yap HH, Chong NL, Jaal (editors). Universiti Sains Malaysia, Penang, Malaysia. pp. 107-114.

7. Rasib KZ (2008) Nature Preceedings: Feeding preferences of Microcerotermes champoni (Snyder) on different timbers dried at different temperatures under choice and no choice trials.

8. Akhtar MS (1974) Zoogeography of the termites of Pakistan. Pakistan Journal of Zoogeography 6: 85-104.

9. Khan RM, Singh AP (1985) Control of termites in wheat crop with insecticides applied through irrigation. Entomologist. 10: 197-201.

10. Anonymous (2000) Global IPM Facility Expert Group on Termite Biology and Management: Finding Alternatives to Persistent Organic Pollutants (PoPs) for Termite Management. Stockholm Convention. Food and Agriculture Organization, Rome, pp: 118-68.

11. Ahmed S, Mustafa T, Riaz MA, Hussain A (2006) Efficacy of insecticides on subterranean termites in sugarcane. Int J Agric Biolo 8: 508-510.

12. Potter MF, Hillery AE (2002) Exterior-targeted liquid termiticides: an alternative approach to managing subterranean termites in buildings. Sociobiology 39: 373-405.

13. Verkerk RHJ, Bravery AF (2001) The UK termite eradication programme: Justification and implementation. Sociobiology 37: 351-360.

14. Maisenhelder LC (1970) Magnolia: (Magnolia grandiflora and Magnolia virginiana). American Woods FS-245. USDA Forest Service.

15. Hodges JD, Evans DL, Garnett LW, Londo A, McReynolds L (2010) Mississippi trees. Miss. State Univ. Ext. Service. Miss. Forestry Commission. Jackson, Mississippi.

16. USNA (United States National Arboretum) (2006) Magnolia questions and answers. National Arboretum. Washington, DC.

17. Venkateswara RJ, Parvathi K, Kavitha P, Jakka NM, Pallela R (2005) Effect of chlorpyrifos and monocrotophos on locomotor behaviour and 
Citation: Rasib KZ, Arif, Aihetasham, A, Alvi DA (2017) Bioactivity of Some Plant Extracts Against Termite Odontotermes obesus (Rambur) (Blattodea: Termitidae). J Biodivers Biopros Dev 4: 167. doi:10.4172/2376-0214.1000167

Page 7 of 7

acetylcholinesterase activity of subterranean termites, Odontotermes obesus. Pest Manag Sci 61: 417-421.

18. Coats JR (1994) Risks from natural versus synthetic insecticides. Annu Rev Entomol 39: 489-515.

19. Logan JWM, Cowie RH, Wood TG (1990) Termite (Isoptera) control in agriculture and forestry by non-chemical methods: a review. Bull Entomol Res 80: 309-330.

20. Zhu BC, Henderson G, Chen F, Fei H, Laine RA (2001) Evaluation of vetiver oil and seven insect active essential oils against the Formosan subterranean termite. J Chem Ecol 27: 1617-1625.

21. Isman MB (2006) Botanical insecticides, deterrents, and repellents in modern agriculture and an increasingly regulated world. Annu Rev Entomol 51: 45-66.

22. Ahmed S, Qasim M (2011) Foraging and chemical control of subterranean termites in a farm building at Faisalabad, Pakistan. Pak J Life Social Scie, 9: 58-62.

23. Singh G, Singh OP, Prasad YR, de-Lampasona MP, Catalan (2004) Chemical and insecticidal repellency, toxicity and tunneling of subterranean termite Heterotermes indicola (Wasmann). J App Environ Biol Scie 1: 107-114

24. Blaske VU, Hertel H, Forschle BT (2003) Repellent effect of isoborneol on subterranean termites (Isoptera: Rhinotermitidae) in soils of different composition. J Econ Entomol, 96: 1267-1274.

25. Singh M, Lal K, Singh SB, Singh M (2002) Effect of Calotropis (Calotropis procera) extract on investigations in leaf oil of Coleus amboinicus Lour. Flavour Fragr J 17: 440- 442

26. Ogunsina OO, Oladimeji MO, Faboro EO (2009) Mortality and antifeedants evaluation of hexane and ethanol extracts of Lantana camara (Verbenaceae), African nutmeg (Monodoro myristica (Gaerth) Dunal) and Enuopiri (Euphorbia Laterifloria, Schum and Thonner) against subterranean termite workers (Macroterme michaelseni). Toxicological and Environmental Chemistry 91: 971-977.

27. Upadhyay RK, Jaiswal G, Ahmad S (2010) Antitermite efficacy of Capparis decidua and its combinatorial mixtures for the control of Indian white termite Odontotermes obesus (Isoptera: Odontotermitidae) in Indian soils. J App Scie Environ Manag 14: 101-105.

28. Manzoor F, Beena W, Malik S, Naz N, Naz S et al. (2011) Preliminary evaluation of Ocimum sanctum as toxicant and repellent against termite, Heterotermes indicola (Wasmann) (Isoptera: Rhinotermitidae). Pak J Scie, 63: 59-62.

29. Elango G, Rahuman AA, Kamaraj C, Bagavan A, Zahir AA et al. (2012) Efficacy of medicinal plant extracts against Formosan subterranean termite, Coptotermes formosanus. Industrial Crops and Products, 36: 524-530

30. Adebowale KO, Adedire CO (2006) Chemical composition and insecticidal properties of the underutilized Jatropha curcas seed oil. Afr J Biotechnol 5: 901-906.

31. Singh N, Kumar S (2008) Antitermite activity of Jatropha curcas Linn. biochemicals. J App Scie Environ Manag 12: 67-69.

32. Elsayed G (1997) The effectiveness of certain plant extracts in controlling the potato tuber moth, Phthorimea operculella. Proceeding of the 6th International Conference on Environment Protection is a Must, Organized by N.I.O.F. and I.S.A.

33. Ganapaty S, Thomas PS, Fottso S Laatsch H (2004). Antitermitic quinines from Diospyros sylvatica. Photochemistry. 65:1265-1271.

34. Han MK, Kim S, Ahn YJ (2006) Insecticidal and antifeedant activities of medicinal plant extracts against Attagenus unicolor japonicus (Coleoptera : Dermestidae). J Stored Products Res. 42: 5-22.

35. Chen K, Ohmura W, Doi S, Aoyama M (2004) Termite feeding deterrent from Japanese Iarch Wood. Bioresource Technol. 95: 129-134.

36. Doolittle M, Raina A, Lax A, Boopathy R (2007) Effect of natural products on gut microbes in Formosan subterranean termite, Coptotermes formosanus. International Biodeterioration \& Biodegradation. 59: 69-71.

37. Verma RK, Verma SK (2006) Phytochemical and termiticidal study of Lantana camara var. Aculeate leaves. Fitoterapia 77: 466-468.

38. Raguraman S, Singh D (1997) Biopotentials of Azadirachtaindica and Cedrusdeodara oils on Callosobruchuschinensis. J Pharmacol 35 344-348.

39. Gbolade AA (2001) Plant-derived insecticides in the control of malaria vector. J Tropicl Med Plants 2: 91-97.

40. Jacobson M (1983) Plants-The potentials for extracting protein, medicines, and other useful chemicals. Workshop Proceedings Congressional Office of Technology, Washington DC: 138-146.

41. Murty US, Jamil K (1987) Effect of south Indian vetiver against immatures of ulexquinquefasciatus. Inter Pest Control 29: 8-9.

42. Sadik F (1973) Handbook of Non-prescription Drugs: American Pharmacology Association. Washington DC.

43. Oyedele AO, Orafidiya LO, Lamikanra A, Olaifa JI (2000) Volatility and mosquito repellency of Hemizygiawelwitschii oil and its formulations. Insect SciAppl 20:123-128. 